\title{
Growth of Acetabularia calyculus in Three Different Media
}

\author{
Y. Yoneshigue Braga \\ Instituto des Pesquisas da Marinha, Projeto Cabo Frio, Arraial do Cabo 28910, Rio de Janeiro, Brazil
}

ABSTRACT: Acetabularia calyculus (Dasycladaceae) has been cultivated in three different media: (1) enriched sea water; (2) artificially upwelled deep sea water; (3) tropical surface sea water. The alga is able to complete its life cycle only in the enriched sea water. Cultured $A$. calyculus cells are not calcified. They show several types of morphological anomalies which deserve further investigation. A. calyculus, like other Acetabularia species, may be useful for studies on morphogenesis regulation.

\section{INTRODUCTION}

Members of the giant unicellular marine alga genus Acetabularia are suitable objects not only for investigations on the subtle relationships between nucleus and cytoplasm but also for ecological and biological research (Puiseux-Dao, 1970; Arasaki and ShihiraIshikawa, 1979; Cinelli, 1979). A. calyculus is widely distributed along the Brazilian coast (Joly and Cordeiro, 1962; Joly, 1965; Pinheiro-Vieira and Ferreira, 1968; Oliveira Filho, 1977) and has recently been found in hypersaline waters in the Araruama Lagoon associated with $A$. schenckii (Oliveira Filho, 1977). The life history of $A$. calyculus has been studied by Arasaki (1942). This paper deals with the growth of $A$. calyculus in three different culture media: (1) enriched sea water; (2) artificially upwelled deep-sea water; (3) tropical surface sea water.

\section{MATERIALS AND METHODS}

Cultures of Acetabularia calyculus Quoy et Gaimard were obtained from fertile plants collected in the Araruama Lagoon, Brazil. The mature reproductive caps containing the cysts (gametangia) were cut from the plants, washed 10 times with sterile sea water and then kept at $10^{\circ} \mathrm{C}$ in the dark for $10 \mathrm{~d}$. After this dark period, the caps were transferred into flasks containing $300 \mathrm{ml}$ of culture medium. Sterilized bivalve shells were added to some flasks to investigate the eventual effect of a calcareous substrate on cell growth. The cultures were made under $12-12 \mathrm{~h}$ light dark cycle (fluorescent tubes) at $27^{\circ}-29^{\circ} \mathrm{C}$, in three different

(c) by Inter-Research media: (1) enriched sea water (Erdschreiber medium; Lateur and Bonotto, 1973; Ukeles, 1976; (2) untreated deep water, artificially upwelled from a 50-m depth, south of Cabo Frio Island; (3) filtered sterile surface sea water from Enseada dos Anjos Bay. Their chemical composition is listed in Table 1.

Culture media were renewed once a week. Germanium dioxide was used to inhibit the growth of contaminant diatoms (Stein, 1973). Cell length was measured with millimeter paper beneath the container (Petri dish).

Table 1. Chemical composition of the 3 culture media used for growing Acetabularia calyculus

\begin{tabular}{|cccc|}
\hline Compound & $\begin{array}{c}\text { Erdschreiber } \\
\text { medium }\end{array}$ & $\begin{array}{c}\text { Upwelled } \\
\text { sea water }\end{array}$ & $\begin{array}{c}\text { Surface } \\
\text { sea water }\end{array}$ \\
\hline $\mathrm{NO}_{3}\left(\mu \mathrm{g}\right.$-at $\left.\mathrm{N}^{-1}\right)$ & 6.54 & 11.90 & 4.18 \\
$\mathrm{NO}_{2}\left(\mu \mathrm{g}\right.$-at $\left.\mathrm{N}^{-1}\right)$ & - & 0.12 & 0.26 \\
$\mathrm{NH}_{3}\left(\mu \mathrm{g}-\mathrm{at} \mathrm{N}^{-1}\right)$ & - & 2.00 & 2.81 \\
$\mathrm{PO}_{4}\left(\mu \mathrm{g}\right.$-at $\left.\mathrm{P}^{-1}\right)$ & 0.54 & 1.03 & 0.35 \\
$\mathrm{Soil}_{\text {extract }(\mathrm{ml})}$ & 50 & - & - \\
\hline
\end{tabular}

\section{RESULTS}

\section{Effect of Culture Media on Development}

The results obtained with three different media are shown in Figure 1. Erdschreiber medium with calcareous substrate gave the best growth. Surface sea water allowed only poor growth, the plants remaining at the vegetative stage (Stage 4 according to Bonotto and 


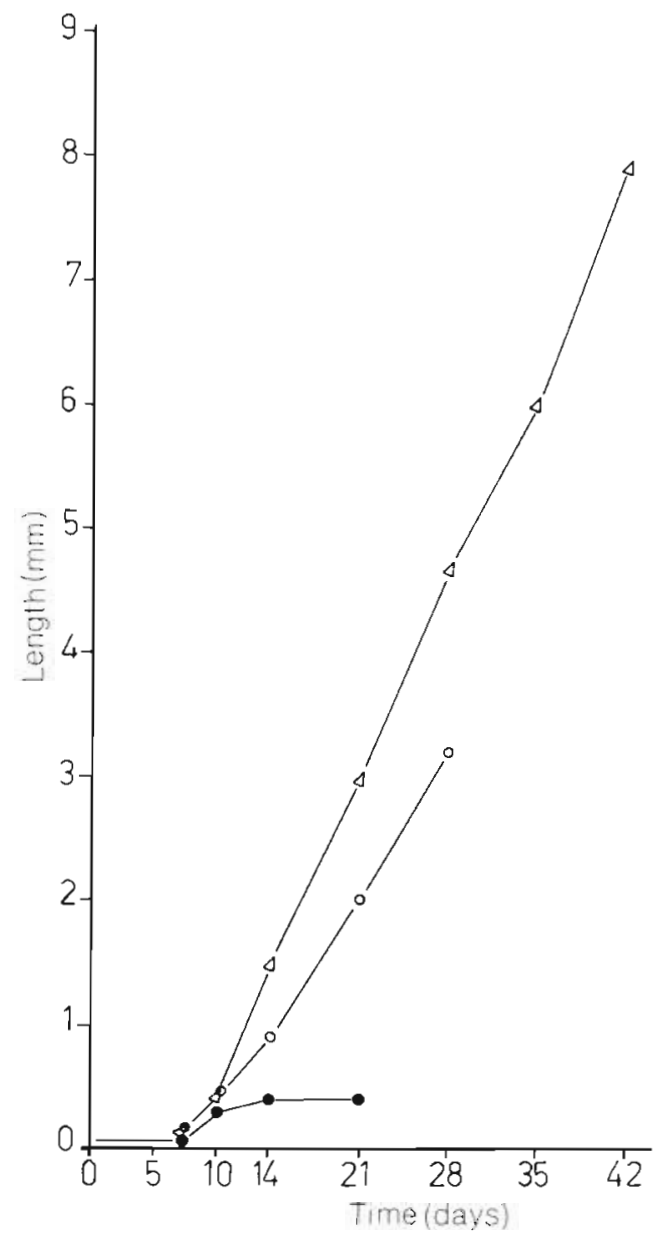

Fig. 1. Acetabularia calyculus. Growth in three different culture media: ^ Erdschreiber medium; o artificially upwelled deep sea water; • tropical surface sea water

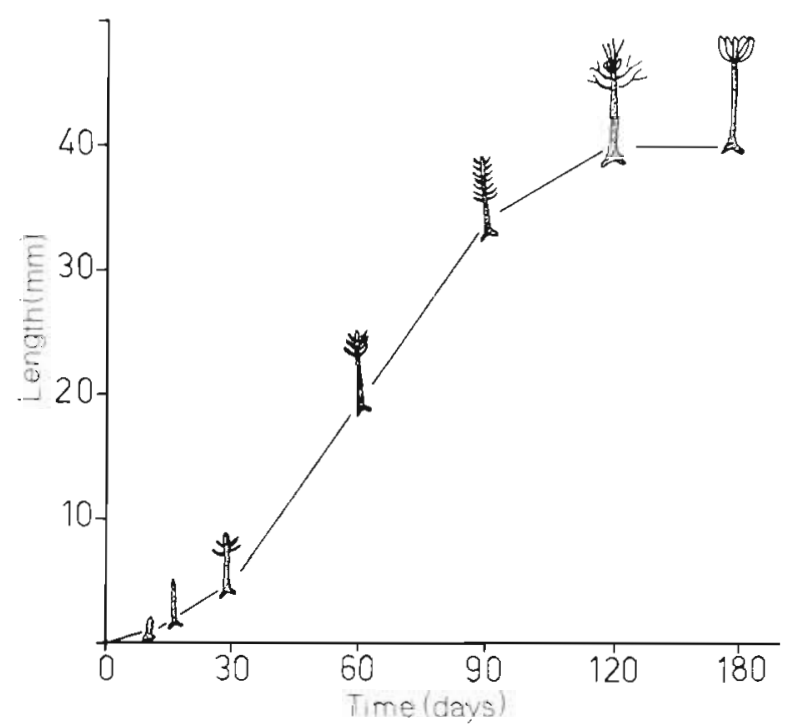

Fig. 2. Acetabularia calyculus. Growth in Erdschreiber medium plus calcareous substrate
Kirchmann, 1970). Upwelled sea water permitted better growth, but again the plants remained at the vegetative stage. Under optimal growth conditions, Acetabularia calyculus cells needed 6 months to reach maturity (reproductive phase). Cultured cells were not calcified.

\section{Effect of Calcareous Substrate on Growth}

The presence of sterilized bivalve shells in the culture flasks did not affect cell growth during the first stages of development. Later, however, plants attached to the calcareous shells showed more rapid growth, reaching maturity at $4-\mathrm{cm}$ length (Fig. 2).

\section{Morphology of Acetabularia calyculus Grown in the Laboratory}

Young germlings of Acetabularia calyculus show a marked polarity; they develop a growing stalk (Fig. 3 A, B, C). The latter forms one or more sterile whorls of branched hairs (Fig. $3 \mathrm{D}$ and $4 \mathrm{~A}$ ) and then the reproductive cap, which comprises $25-35$ rays (Fig. 4 C, D, E, F). Numerous spherical cysts (gametangia) form in the cap's rays (Fig. $4 \mathrm{G}, \mathrm{H}$ ). The cysts of $A$. calyculus, like those of other Acetabularia species, possess a lid (Fig. 4 I) through which the gametes are released.

Cultured Acetabularia calyculus may develop morphological anomalies: branching of the stalk (Fig. $3 \mathrm{C}$ ), enlargement of first and second order articles of the sterile whorls (Fig. 4 B), or formation of abnormal caps (Fig. 4 C) with a reduced number of rays.

\section{DISCUSSION}

The results reported show that the best growth of Acetabularia calyculus is obtained with Erdschreiber medium. Although upwelled water is rich in nitrate and phosphate (Table 1), it is unable to sustain satisfactory growth. Surface sea water seems a rather poor culture medium for $A$. calyculus. Our findings suggest that the compounds present in the soil extract promote development. It is known that amino acids and ammonia are present in soil extracts (Bonotto, 1976). Possibly, soil extracts contain other organic substances required for the growth of Acetabularia. We have observed that the growth of phytoplankton is also poor in upwelled waters, in spite of the fact that the latter are rich in nutrient salts (Yoneshigue-Braga et al., 1979). Probably, important factors such as chelating substances (Barber et al., 1971) are lacking in the upwelled waters used in our laboratory. Cultured $A$. 


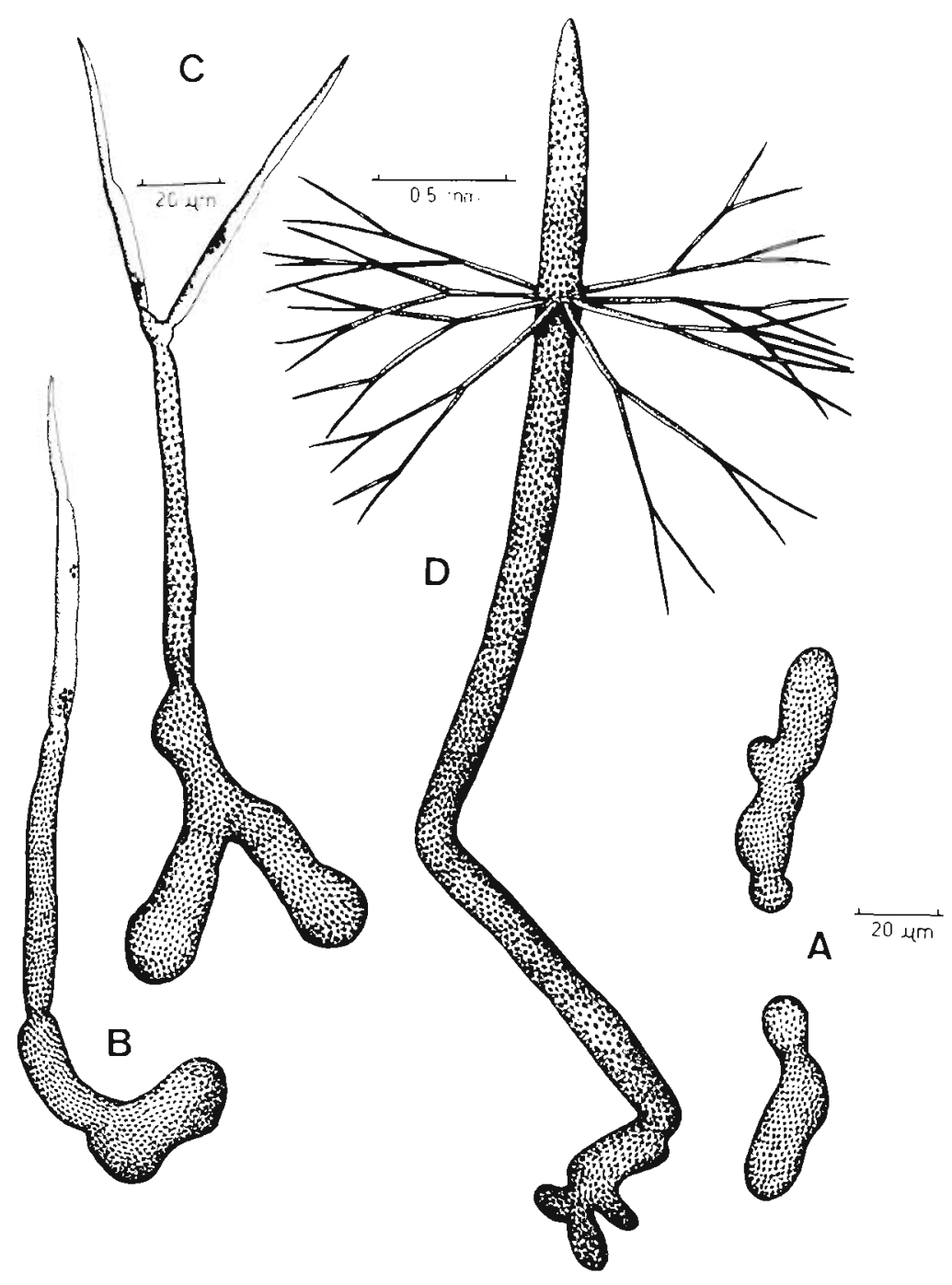

Fig. 3. Acetabularia calyculus. Young germlings. A: Germinating zygotes; B and C: growing stalks; D: formation of first sterile whorl of branched hairs

calyculus cells are not calcified. Observations with the optical microscope failed to detect the presence of a very thin layer of lime, revealed by a scanning electron microscope in A. mediterranea cells (Berger et al., 1974). That plants attached to shells show better growth is particularly interesting: in nature, Acetabularia is frequently found on a calcareous substrate (Patel and Francis, 1970); Arasaki and Shihira-Ishikawa (1979) observed that this alga is able to perforate and penetrate dead shell pieces. Biochemical investigations appear necessary in order to establish whether the alga is capable of utilizing shell substances.

The morphological anomalies observed in our cultures are difficult to explain. Similar anomalies were found in laboratory cultures of Acetabularia mediterra- nea (Bonotto, 1970). The artificial growth conditions provided do not seem to be the only factor responsible for heteromorphoses, since cells with abnormal morphological traits were also found in nature (Woronin, 1861; Bonotto, 1970). Our observations on A. calyculus are in agreement with those of Arasaki (1942) and underline the suitability of Erdschreiber medium for cultivating these algae in the laboratory.

Acknowledgements. I wish to thank Dr. Serge Y. Maestrini for reading the manuscript; Admiral Paulo Moreira da Silva, Captain Roberto Fernandes Rodrigues, Dr. Jean L. Valentin and my colleagues for kind advice and encouragement during the study. This work was partially supported by Grant 1111.2326/76 from the National Research Council of Brazil. 

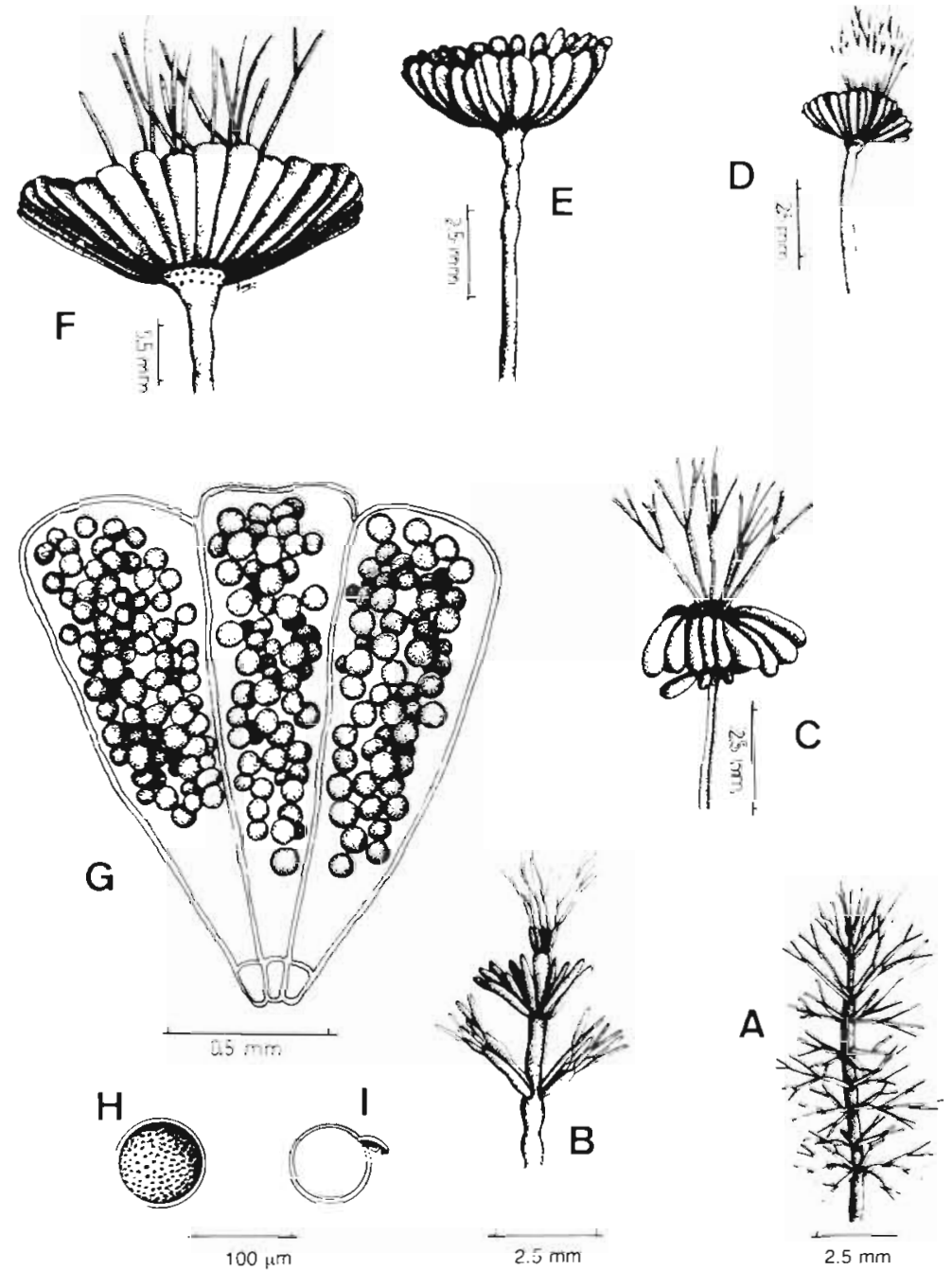

Fig. 4. Acetabularia calyculus. A: Vegetative cell bearing 8 whorls of branched hairs; B: abnormal enlargement of first and second articles of sterile whorls; C: abnormal cap with reduced number of rays; D and F: normal reproductive cap; E: mature cap without sterile hair whorls; G: rays with cysts (gametangia); H: free cyst; I: empty cyst showing the lid through which gametes were released

\section{LITERATURE CITED}

Arasaki, S. (1942). On the life-history of Acetabularia calyculus Quoy et Gaimard. Botany Magazine (Tokyo) 56: 383-391

Arasaki, S., Shihira-Ishikawa, I., Bonotto, S., Kefeli, V., Puiseux-Dao, S. (eds) (1979). Distribution and ecology of Acetabularia in Japan. In: Developmental biology of Acetabularia. Elsevier/North-Holland Biomedical Press, Amsterdam, pp. 15-18

Barber, R. T., Dugdale, R. C., MacIsaac, J. J. Smith, R. L. (1971). Variations in phytoplankton growth associated with the source and conditionery of upwelling water. Investigation Pesq. 35: 171-193

Berger, S., Sandakhchiev, L. S., Schweiger, H. G. (1974). Fine structural and biochemical markers of Dasycladaceae. J. Microsc. 19: 89-104

Bonotto, S. (1970). Morphogenèse d'Acetabularia mediterranea dans la mer et en laboratoire. Bull. Soc. Roy. Bot. Belgique 103: 213-223

Bonotto, S. (1976). Cultivation of plants. Multicellular plants.
In: Kinne, O. (ed.), Marine ecology, Volume III, Cultivation. Wiley, London, pp. 467-501

Bonotto, S., Kirchmann, R. (1970). Sur les processus morphogénétiques d'Acetabularia mediterranea. Bull. Soc. Roy Bot. Belgique 103: 255-272

Cinelli, F. (1979). Acetabularia acetabulum (L) Silva, Acetabularia parvula Solms-Laubach and Dasycladus vermicularis (Scopoli) Krasser (Chlorophyta, Dasycladaceae): Ecology and distribution in the Mediterranean Sea. In: Bonotto, S., Kefeli, V., Puiseux-Dao, S. (eds) Developmental biology of Acetabularia. Elsevier/North-Holland Biomedical Press, Amsterdam, pp. 3-14

Joly, A. B., Cordeiro, M. (1962). Addition to the marine flora of Brazil. II. Boln Fac. Cienc. Letr. Univ. S. Paulo, 257 (Bot. 18): $223-228$

Joly, A. B. (1965). Flora marinha do litoral norte do Estado de São Paulo e regiōes circunvizinhas. Boln Fac. Cienc. Letr. Univ. S. Paulo, 294 (Bot. 21): 11-267

Lateur, L., Bonotto, S. (1973). Culture of Acetabularia mediterranea in the Laboratory. Bull. Soc. Roy. Bot. Belgique 106: $17-38$ 
Oliveira Filho, E. C. (1977). Algas marinhas bentônicas do Brasil. Tese de livre docência. Dep. de Bot., Inst. Biocienc., Univ. S. Paulo

Patel, R. J., Francis, M. A. (1970). Acetabularia mobii SolmsLaubach and Neomeris annulata Dickie from India. Phy$\cos 9: 52-54$

Pinheiro-Vieira, F., Ferreira, M. M. (1968). Segunda contribuiçāo ao inventário das algas marinhas bentonicas do nordeste brasileiro. Arq. Est. Mar. Univ. Fed. Ceará 8 (1): $75-82$

Puiseux-Dao, S. (1970). Acetabularia and cell biology, Logos Press, London
Stein, J. R. (1973). Handbook of phycological methods and growth measurements, Cambridge University Press, Cambridge

Ukeles, R. (1976). Cultivation of plants: unicellular plants. In: Kinne, O. (ed.) Marine ecology, Vol. III, Cultivation. Wiley, London, pp. 367-466

Woronin, H. (1861). Recherches sur les algues marines Acetabularia Lamx et Espera Dcne. Annls Sci. nat. 16: 200-214

Yoneshigue-Braga, Y. Maestrini, S. Y., Rodriguez, E. G. (1979). Fertilité et facteurs limitants de la croissance des producteurs primaires des eaux de l'upwelling de Cabo Frio (Brésil). Etude préliminaire. C. r. hebd. Séanc. Acad Sci., Paris 288: 135-138

This paper was presented by Professor S. Bonotto; it was accepted for printing on May 31, 1980 